\title{
Age and Sex Differences in the Genetics of Cardiomyopathy
}

Oyediran Akinrinade ${ }^{1}$, Genomics England Research Consortium ${ }^{2,3}$, Jane Lougheed ${ }^{4}$, Tapas

Mondal $^{5}$, John Smythe ${ }^{6}$, Luis Altamirano-Diaz ${ }^{7}$, Erwin Oechslin ${ }^{8}$, Seema Mital ${ }^{1,9,10}$

${ }^{1}$ Genetics and Genome Biology Program, The Hospital for Sick Children, Toronto, Ontario, Canada

${ }^{2}$ Genomics England, London, UK

${ }^{3}$ William Harvey Research Institute, Queen Mary University of London, London, UK

${ }^{4}$ Division of Cardiology, Children's Hospital of Eastern Ontario, Ottawa, Ontario, Canada

${ }^{5}$ Division of Cardiology, Department of Pediatrics, McMaster Children's Hospital, Hamilton,

ON, Canada

${ }^{6}$ Division of Cardiology, Department of Pediatrics, Kingston General Hospital, Kingston, ON,

Canada

${ }^{7}$ Division of Cardiology, Department of Pediatrics, London Health Sciences Centre, London,

ON, Canada

${ }^{8}$ Division of Cardiology, Toronto Adult Congenital Heart Disease Program at Peter Munk

Cardiac Centre, Department of Medicine, University Health Network, and University of Toronto,

Toronto, ON, Canada

${ }^{9}$ Ted Rogers Centre for Heart Research, Toronto, Ontario, Canada

${ }^{10}$ Division of Cardiology, Department of Pediatrics, The Hospital for Sick Children, University of Toronto, Toronto, Ontario, Canada 
medRxiv preprint doi: https://doi.org/10.1101/2021.04.06.21255002; this version posted April 8, 2021. The copyright holder for this preprint (which was not certified by peer review) is the author/funder, who has granted medRxiv a license to display the preprint in perpetuity.

It is made available under a CC-BY-NC-ND 4.0 International license.

\section{Corresponding Author:}

Seema Mital, MD

Hospital for Sick Children,

555 University Avenue,

Toronto, Ontario M5G 1X8, Canada.

Tel: 416-813-7418; Fax: 416-813-5857

E-mail: seema.mital@ sickkids.ca 
medRxiv preprint doi: https://doi.org/10.1101/2021.04.06.21255002; this version posted April 8, 2021. The copyright holder for this preprint (which was not certified by peer review) is the author/funder, who has granted medRxiv a license to display the preprint in perpetuity.

It is made available under a CC-BY-NC-ND 4.0 International license .

\begin{abstract}
Aims: Cardiomyopathy is a clinically and genetically heterogeneous disorder with age and sexrelated differences in severity and outcomes. The aim of our study was to identify age and sexrelated differences in the genetic architecture of cardiomyopathy.
\end{abstract}

Methods and Results: We analyzed whole genome sequence data from 471 pediatric and 926 adult cardiomyopathy patients from our Heart Centre Biobank and from the Genomics England cohort. Overall yield of rare deleterious coding variants was higher in pediatric compared to adult onset cardiomyopathy, but not different by sex. MYH7, TNNT2, MYL3, and VCL variants were more frequent in pediatric patients; TTN and $O B S C N$ variants were more frequent in adult patients, with $M Y H 7$ (Odds ratio 3.6; CI 2.1-6.3) and OBSCN (Odds ratio 5.5, CI 2.0-21.4) remaining significant after adjusting for multiple testing. Variants in early-onset cardiomyopathy clustered in highly constrained coding regions compared to those in adult patients $\left(\mathrm{p}=3.9 \times 10^{-3}\right)$. There were also differences between pediatric and adult patients in variant location within $M Y H 7$ and TTN genes. When analyzed by sex, variants in female compared to male patients were in more highly constrained coding regions $(\mathrm{p}=0.002)$.

Conclusion: Our findings highlight under-appreciated genetic differences in early versus late onset cardiomyopathy. Variants in childhood cardiomyopathy and in female patients were in highly constrained coding regions of the genome suggesting greater deleterious effects and strong purifying selection in the general population. Knowledge of the affected gene, variant location within the gene, and variant constraint scores may be useful in predicting early versus late onset cardiomyopathy.

Key words: Cardiomyopathy, genetic, whole genome sequencing, age, sex, genomic constraints 


\section{Introduction}

Cardiomyopathies are genetic disorders of heart muscle that cause the heart to become dilated and weak, or hypertrophied and stiff. Phenotypically, there are five subtypes - dilated (DCM), hypertrophic (HCM), restrictive (RCM), left ventricular non-compaction cardiomyopathy (LVNC) and arrhythmogenic cardiomyopathy (ACM), with a significant overlap between phenotypes and genotypes. ${ }^{1}$ Together, cardiomyopathies are the most frequent indication for heart transplantation and the leading cause of sudden cardiac death. ${ }^{2-6}$ Variants in over 100 genes have been associated with cardiomyopathy. While cardiomyopathies can be secondary to infection, inflammation, syndromic disorders, neuromuscular disorders, inborn errors of metabolism, or drug toxicities, primary cardiomyopathies i.e. those isolated to the heart, are usually genetic, can be sporadic or familial, and usually have an autosomal dominant inheritance. $^{7-9}$

Cardiomyopathies have high childhood penetrance with variable expressivity resulting in intrafamilial and inter-familial variability in the age of onset and severity. ${ }^{10,11}$ Studies have also reported sex-related differences with a higher incidence and severity of cardiomyopathy in males compared to females. ${ }^{12-17}$ While age-related penetrance, lifestyle factors, and hormonal differences can explain part of the clinical variability by age and sex, a systematic comparison of the genetics of childhood versus late onset cardiomyopathy or of disease in females versus males has not been performed. 
Growth in publicly available large-scale human genomic variation datasets has enabled identification of disease-associated genes through case-control burden analyses, and provides an opportunity to study the distribution of variation within genes, identify mutational hotspots, ${ }^{18,19}$ and define genes that are intolerant of variants through gene-level metrics such as Residual Variation Intolerance Score (RVIS) and pLI (probability of being loss of function intolerant) score. ${ }^{19,20}$ Additionally, Havrilla et al. developed a map of constrained coding regions in the human genome that are under strong purifying selection and show a scarcity of variants in the general population. ${ }^{21}$ Variants found in these constrained regions are more likely to be associated with developmental and disease phenotypes.

The goal of our study was to evaluate age and sex-related differences in the genetics of cardiomyopathy by comparing the frequency and distribution of rare, deleterious variants within known cardiomyopathy genes and within constrained regions of these genes between pediatric and adult patients, and between male and female patients. 


\section{Methods}

Study cohort: The study cohort comprised 1397 unrelated primary cardiomyopathy patients (471 were pediatric i.e. $<18$ years old at diagnosis; 926 were adult); 236 were consented through the multi-center SickKids Heart Centre Biobank Registry and 1161 patients were from the 100,000 Genomes Project accessed through the Genomics England Clinical Interpretation Partnership (version 8). ${ }^{22,23}$ Cardiomyopathy phenotypic subtypes were defined by published clinical criteria. ${ }^{3,24}$ Written informed consent was obtained from all biobank participants and/or their parents or legal guardians and the research protocol was approved by the Institutional Research Ethics Boards at the Hospital for Sick Children, Children's Hospital of Eastern Ontario, Toronto General Hospital, London Health Sciences Centre, Kingston General Hospital, and Hamilton Health Sciences Centre. Patients with secondary cardiomyopathies resulting from inborn errors of metabolism, mitochondrial disorders, syndromic, and neuromuscular etiologies were excluded.

Whole genome sequencing and variant interpretation: Whole genome sequencing (WGS) was performed on DNA derived from blood or saliva using Illumina HiSeq $\mathrm{X}$ to an average depth of 30X. WGS quality control, data processing, and variant identification were done as previously described. ${ }^{25}$ Identified variants were annotated using Ensembl's Variant Effect Predictor (VEP v92). ${ }^{26}$ Rare missense variants predicted deleterious or damaging by SIFT and PolyPhen tools with Combined Annotation Dependent Depletion score of at least 20 were classified as "deleterious" ${ }^{27-29}$ Variants predicted to cause loss-of-function (LoF) i.e. frameshift, nonsense, and splice-site variants, were annotated by LOFTEE via VEP, and rare variants 
medRxiv preprint doi: https://doi.org/10.1101/2021.04.06.21255002; this version posted April 8, 2021. The copyright holder for this preprint (which was not certified by peer review) is the author/funder, who has granted medRxiv a license to display the preprint in perpetuity. It is made available under a CC-BY-NC-ND 4.0 International license .

flagged as high confidence LoF by LOFTEE were classified as deleterious. ${ }^{30}$ Rare variants were defined based on Minor Allele Frequency (MAF) $<0.01 \%$ in Exome Aggregation Consortium reference individuals. Only coding single nucleotide variants (SNVs) and small insertiondeletions were assessed in this study.

Cardiomyopathy candidate gene sets: Using information from Online Mendelian Inheritance in Man database, published literature, and genes represented on commercially available cardiomyopathy gene panels, we manually curated a list of 133 cardiomyopathy candidate genes (Supplementary Table S1). 56 genes with strongest association with cardiomyopathy were classified as Tier 1; these included the sarcomeric genes. Based on gene ontology, we grouped the 133 genes into 14 functional categories.

Variants mapping to protein domains and constrained coding regions: Variants identified in genes with multiple transcripts were reported with respect to the canonical transcripts, and were mapped to uniprot protein domains. Protein domain annotation for all canonical transcripts of cardiomyopathy genes were obtained by mining the uniprot database (http://www.uniprot.org) (assessed May 28, 2020) using a custom in house script. ${ }^{31}$ We accessed the constrained coding region (CCR) map as published by Havrilla et al. ${ }^{21}$, and using this map, we obtained CCR score for all variants. By converting genomic coordinates to protein coordinates, we used the CCR map to obtain a measure of constraint on protein domains of cardiomyopathy genes.

Statistical analysis: All rare coding SNVs and insertions-deletions predicted deleterious or high risk for altering protein function of known cardiomyopathy genes were used in the final analysis. 
Variant yield and burden of multiple variants in pediatric versus adult, and male versus female cases were compared for all cardiomyopathy patients as well as for the subset with only HCM and DCM. CCR scores were compared using Kolmogorov-Smirnov (KS) two-tailed test to determine if variants from different subgroups had variable distribution in cardiomyopathy patients and in reference control genomes available through the Genome Aggregation Database (gnomAD v2.1) ( $\mathrm{n}=125,748)$. The uniformity of the spatial distribution of deleterious variants within proteins was assessed by KS Goodness-of-Fit Test. Comparisons between groups were performed with either $\chi^{2}$ test or Fisher's exact test. Continuity correction was applied via Visualizing Categorical Data (vcd) R package (v1.4-8) to estimate odds ratio and confidence interval for any zero cells in the contingency table. ${ }^{32}$ Benjamini-Hochberg false discovery rate correction was performed on all analyses to adjust for multiple testing. All statistical analyses were performed using R statistical software (version 3.5.2). 
medRxiv preprint doi: https://doi.org/10.1101/2021.04.06.21255002; this version posted April 8, 2021. The copyright holder for this preprint (which was not certified by peer review) is the author/funder, who has granted medRxiv a license to display the preprint in perpetuity.

It is made available under a CC-BY-NC-ND 4.0 International license .

\section{Results}

\section{Study population}

Whole genome sequencing data was available on 1397 eligible cardiomyopathy patients. 471 (34\%) were pediatric cases, and 871 (62\%) were male. By subtype, 768 (55\%) had HCM, 435 (31\%) had DCM, $116(8 \%)$ had ACM, 58 (4\%) had LVNC, and $20(1 \%)$ had RCM. The cohort characteristics are described in Table $\mathbf{1 .}$

\section{Genetic differences in early versus late onset cardiomyopathy}

Higher frequency of deleterious variants in pediatric cardiomyopathy: Overall, 635 patients (45\% of the cohort) harbored one or more rare deleterious variants across 111 genes. Of these, 395 (28\% of the overall cohort) harbored variants in 52 of the 56 Tier 1 genes. A higher proportion of pediatric patients harbored a deleterious variant in a Tier 1 gene compared to adults ( $32 \%$ vs $27 \%$ respectively, $\mathrm{p}=0.04$ ). When analyzed by cardiomyopathy subtypes, a higher proportion of pediatric HCM cases harbored a deleterious variant compared to adult HCM (34\% vs $23 \%$ respectively, $\mathrm{p}=0.004$ ); this difference was not seen in DCM cases (Figure 1a). There was no significant difference in the proportion of patients harboring multiple deleterious variants between pediatric and adult cases (Figure 1b).

Higher variant CCR scores in pediatric cardiomyopathy: We obtained the CCR score for all deleterious variants identified in cardiomyopathy genes in our study cohort and in gnomAD. As expected, deleterious variants identified in cardiomyopathy patients were in more constrained 
medRxiv preprint doi: https://doi.org/10.1101/2021.04.06.21255002; this version posted April 8, 2021. The copyright holder for this preprint (which was not certified by peer review) is the author/funder, who has granted medRxiv a license to display the preprint in perpetuity. It is made available under a CC-BY-NC-ND 4.0 International license .

coding regions compared to those in the gnomAD reference population i.e. had higher CCR scores (KS test $\mathrm{p}=2.2 \times 10^{-14}$ ) (Figure 2a, c). This difference was also seen in the subset of Tier 1 genes (KS test $\left.\mathrm{p}=1.1 \times 10^{-15}\right)($ Figure $2 \mathbf{b}, \mathbf{d})$. For all genes and gene groups with at least 10 variants, we generated variant CCR score density maps (Figures 3a-d) and compared CCR score probability distribution using KS two-tailed test (Figures 3e-h). In the cardiomyopathy cohort, variant CCR scores across all cardiomyopathy genes was higher in pediatric compared to adult cases (KS test $\mathrm{p}=0.0039)$ and also when limited to variants in Tier 1 genes $(\mathrm{KS}$ test $\mathrm{p}=0.0005)$. CCR scores of variants in sarcomeric genes were also higher in pediatric versus adult cases (KS test $\mathrm{p}=0.0031)$. Variant CCR scores of non-sarcomeric genes did not differ by age (KS test $\mathrm{p}=0.27$ ). Overall, these findings suggest that those with early onset disease are more likely to harbor variants within highly constrained coding regions.

Differentially affected genes in pediatric and adult cardiomyopathy: For gene level analysis, we compared the proportion of patients harboring at least one deleterious variant in a given gene. Figures 4a-c show the proportion of pediatric and adult patients harboring deleterious variants by gene and by variant types. Figures 4 d-f show volcano plots by cardiomyopathy subtype for differentially mutated genes between pediatric and adult cases. Five genes were differentially mutated between pediatric and adult cases with $M Y H 7$ being the most frequently mutated gene in overall pediatric cardiomyopathy cases. TNNT2, MYL3, and $V C L$ were also more frequently mutated in pediatric versus adult patients (Figure 4d, Supplementary Table S2). Of note, LoF variants in $V C L$ were only seen in children, not in adults $(\mathrm{OR}=13.8, \mathrm{p}=0.038)$. In contrast, $T T N$ truncating variants and $O B S C N$ deleterious variants were more frequent in adults compared to 
medRxiv preprint doi: https://doi.org/10.1101/2021.04.06.21255002; this version posted April 8, 2021. The copyright holder for this preprint (which was not certified by peer review) is the author/funder, who has granted medRxiv a license to display the preprint in perpetuity. It is made available under a CC-BY-NC-ND 4.0 International license .

children with cardiomyopathy (Figure 4d, Supplementary Table S2). Both $M Y H 7$ and $O B S C N$ variant burden differences remained significant after correction for multiple testing.

Subgroup analysis by cardiomyopathy subtype showed that $M Y H 7, M Y L 3$ and $D B H$ were more frequently mutated in pediatric $\mathrm{HCM}$, while $O B S C N$ was more frequently mutated in adult $\mathrm{HCM}$ (Figure 4e, Supplementary Table S2). TTN was the most affected gene in adult DCM accounting for $13.5 \%$ of cases compared to $5.1 \%$ of pediatric DCM. OBSCN was the second most affected gene in adult DCM with a higher variant burden compared to childhood DCM (Figure 4f, Supplementary Table S2). Of note, $F L N C$, a gene that is not routinely captured in all commercially available gene testing panels, was involved in $4.1 \%$ of all DCM cases. Overall, these findings suggest that variants in several sarcomeric and structural genes are more likely to be associated with early onset disease.

Variant burden by gene category in pediatric and adult cardiomyopathy: When analyzed by gene groups, sarcomeric genes were more frequently mutated in pediatric patients, particularly in the subset with HCM (Figure 5, Supplementary Table S3). Conversely, desmosomal genes were more frequently mutated in adult cardiomyopathy, particularly in the subset with DCM. Ion channel genes were also more frequently mutated in adult DCM compared to pediatric DCM (Figure 5, Supplementary Table S3).

Variant location within protein domains: We used goodness of fit test to determine if deleterious variants were uniformly distributed within protein domains of genes or clustered in mutational hotspots within genes. This was analyzed only for genes with a high variant burden 
medRxiv preprint doi: https://doi.org/10.1101/2021.04.06.21255002; this version posted April 8, 2021. The copyright holder for this preprint (which was not certified by peer review) is the author/funder, who has granted medRxiv a license to display the preprint in perpetuity. It is made available under a CC-BY-NC-ND 4.0 International license .

i.e. $>10$, in the overall cohort. Figure $\mathbf{6}$ shows the spatial distribution of deleterious variants in $M Y H 7, M Y B P C 3, T T N$, and $O B S C N$. Deleterious variants were non-uniformly distributed in MYH7 in pediatric patients with variants clustering within the myosin head and neck domains (KS test $\left.\mathrm{p}=8.4 \times 10^{-4}\right)$. In adults, variants were more uniformly distributed across myosin head, neck and tail domains (KS test, $\mathrm{p}=0.058$ ) (Figure 6a). For $M Y B P C 3$, variants clustered within the $\mathrm{C} 5, \mathrm{C} 7$, and $\mathrm{C} 10$ domains but this clustering was not different between children and adults (Figure 6b). TTN truncating variants were non-evenly distributed with clustering in the A-band domain $\left(\mathrm{p}=3.4 \times 10^{-4}\right)$ as has been previously described. ${ }^{33-35}$ Within the A-band, there was nonuniform variant distribution in adults $\left(\mathrm{p}=3.5 \times 10^{-3}\right)$ but not in children $(\mathrm{p}=0.49)$ (Figure 6c). $O B S C N$ deleterious variants were non-evenly distributed and clustered within the protein kinase domain of the gene in adult patients ( $p=0.033$ ) (Figure 6d). Overall, these findings suggest that location within protein domains may influence age-related penetrance of a variant.

\section{Genetic differences by sex}

There was no difference in overall variant yield between male and female patients (871 males, 526 females). There were no sex-related differences in variant CCR scores in gnomAD reference genomes ( $\mathrm{p}=0.51)$ (Figure 7a, d). However, in the cardiomyopathy cohort, the deleterious variant CCR scores were higher in females compared to males. This was true of variants in all cardiomyopathy genes $\left(\mathrm{p}=2.5 \times 10^{-3}\right)($ Figure $7 \mathbf{b}, \mathbf{e})$ as well as for variants in Tier 1 genes $(p=0.019)$ (Figure 7c, f). Interestingly, we found that deleterious variants in LoF intolerant genes identified in female cardiomyopathy patients clustered in more constrained regions than those identified in male cardiomyopathy patients (KS test $\mathrm{p}=0.04)$. At a gene level, only one gene, CPT2, harbored a 10-fold higher burden of deleterious variants in male compared with female 
medRxiv preprint doi: https://doi.org/10.1101/2021.04.06.21255002; this version posted April 8, 2021. The copyright holder for this preprint (which was not certified by peer review) is the author/funder, who has granted medRxiv a license to display the preprint in perpetuity. It is made available under a CC-BY-NC-ND 4.0 International license.

patients ( $\mathrm{p}=0.028)$, while $M Y H 6$ harbored a 12-fold higher variant burden in female versus male patients albeit this difference was only seen in DCM patients $(\mathrm{p}=0.024)$ (Figure 7g). There were no striking differences in variant burden by gene group between male and female patients

(Figure 7h). Overall, these findings suggest that female patients with cardiomyopathy are more likely to harbor variants in constrained coding regions although it is unclear if these differences alone are sufficient to account for sex-related differences in clinical disease severity. 


\section{Discussion}

The genetic architecture of cardiomyopathy is heterogeneous, and disease-causing variants have been identified in over 100 genes. By analyzing variants in known cardiomyopathy genes using WGS, we found a higher genetic yield in pediatric compared to adult patients. Importantly, we found age-related differences in affected genes and proteins and in the distribution of variants within constrained coding regions between childhood and adult cardiomyopathy patients that can have implications for using genetic information to guide predictions of age of disease onset and severity.

A striking finding was that variants in childhood cardiomyopathy clustered within highly constrained coding regions of cardiomyopathy genes compared with those identified in adult patients. This was particularly true of sarcomeric gene variants and variants in Tier 1 cardiomyopathy genes. Additionally, deleterious variants in $M Y H 7$ in childhood cases clustered within myosin head and neck regions with very few variants seen in the tail region unlike adult cases. The head and neck regions of MYH7 contain important domains - ATPase site, actin binding site, the converter, and essential light chain, that play a critical role in myocardial contraction and energetics. ${ }^{36,37}$

To date, truncating variants in the giant sarcomeric gene, titin, located in the A-band region of the gene, have been reported as the most common genetic cause of adult DCM accounting for $20-25 \%$ of cases. ${ }^{33-35,38,39}$ Our findings confirmed that $T T N$ truncating variants were the leading cause of DCM in adult patients but were rare in pediatric patients. Interestingly, OBSCN 
medRxiv preprint doi: https://doi.org/10.1101/2021.04.06.21255002; this version posted April 8, 2021. The copyright holder for this preprint (which was not certified by peer review) is the author/funder, who has granted medRxiv a license to display the preprint in perpetuity.

It is made available under a CC-BY-NC-ND 4.0 International license .

emerged as the second most mutated gene in adult DCM but was rarely mutated in pediatric DCM. Similar to TTN which is a giant protein, OBSCN is a giant protein in the sarcomere that interacts with the z-disk region of TTN. While $O B S C N$ missense and frameshift mutations have been shown to co-segregate with HCM, DCM, and LVNC, ${ }^{40,41}$ our study reveals clustering of $O B S C N$ deleterious variants in the protein kinase domains that interact with $C D H 2$ known to cause $\mathrm{ACM}{ }^{42}$ Taken together, this finding highlights $O B S C N$ as an important contributor to adult cardiomyopathy.

Sex-related phenotype differences have been reported in cardiomyopathy with usually a higher prevalence, earlier onset and greater disease severity in male patients. ${ }^{43-46}$ However, we did not detect significant sex-related differences in the frequency and type of affected genes.

Interestingly, overall deleterious variants identified in female patients had higher constraint scores compared with those identified in male patients. This difference was not seen in the reference population. Specifically, deleterious variants in LoF intolerant genes clustered in more constrained coding regions in female patients compared to those identified in male patients. Taken together, these findings suggest that variants, specially LoF variants in LoF intolerant genes seen in females may be under purifying selection due to greater deleterious effects.

The study has some limitations. The precise age at diagnosis was not known in the adult cases and therefore analysis using age as a linear variable could not be performed. Also, detailed clinical outcomes were not available in the adult cohort, therefore analysis of genotype with outcomes could not be performed. This analysis was limited to coding SNVs and insertion 
medRxiv preprint doi: https://doi.org/10.1101/2021.04.06.21255002; this version posted April 8, 2021. The copyright holder for this preprint (which was not certified by peer review) is the author/funder, who has granted medRxiv a license to display the preprint in perpetuity. It is made available under a CC-BY-NC-ND 4.0 International license.

deletions and did not include copy number variants, structural variants or non-coding regulatory variants.

Overall, our study identified deleterious coding variants in MYH7, MYL3, TNNT2 and VCL as more likely to be associated with childhood onset cardiomyopathy, while variants in $T T N$ and $O B S C N$ were more likely to be associated with adult onset cardiomyopathy. The higher genomic constraints on variants found in pediatric patients and in some female patients suggest that they may be under purifying selection in the general population due to greater deleterious effects. Overall, our findings suggest that affected gene, variant location within the gene, and variant constraint scores may be useful in predicting early versus late onset cardiomyopathy. This knowledge may inform risk stratification by genotype and help with predictive counseling of affected families. 
medRxiv preprint doi: https://doi.org/10.1101/2021.04.06.21255002; this version posted April 8, 2021. The copyright holder for this preprint (which was not certified by peer review) is the author/funder, who has granted medRxiv a license to display the preprint in perpetuity.

It is made available under a CC-BY-NC-ND 4.0 International license.

\section{Acknowledgement}

We acknowledge the Labatt Family Heart Centre Biobank at the Hospital for Sick Children for access to DNA samples for whole genome sequencing, and The Centre for Applied Genomics at the Hospital for Sick Children for performing whole genome sequencing. This research was made possible through access to the data and findings generated by the 100,000 Genomes Project. The 100,000 Genomes Project uses data provided by patients and collected by the National Health Service as part of their care and support.

\section{Funding}

This work was funded by the Ted Rogers Centre for Heart Research (SM). SM holds the Heart and Stroke Foundation of Canada / Robert M Freedom Chair in Cardiovascular Science. EO holds the Bitove Family Professorship of Adult Congenital Heart Disease. The 100,000 Genomes Project is managed by Genomics England Limited (a wholly owned company of the Department of Health and Social Care) and funded by the National Institute for Health Research and NHS England. The Wellcome Trust, Cancer Research UK and the Medical Research Council have also funded research infrastructure.

\section{Conflict of interest}

The authors have no conflicts of interest to disclose.

\section{Consortia}

Genomics England Research Consortium 
Ambrose, J. C. ${ }^{1}$; Arumugam, P. ${ }^{1}$; Bleda, M. ${ }^{1}$; Boardman-Pretty, F. ${ }^{1,2}$; Boustred, C. R. ${ }^{1}$; Brittain, H. ${ }^{1}$; Caulfield, M. J. ${ }^{1,2}$; Chan, G. C. ${ }^{1}$; Fowler, T. ${ }^{1}$; Giess A. ${ }^{1}$; Hamblin, A. ${ }^{1}$; Henderson, S. ${ }^{1,2}$; Hubbard, T. J. P. ${ }^{1}$; Jackson, R. ${ }^{1}$; Jones, L. J. ${ }^{1,2}$; Kasperaviciute, D. ${ }^{1,2}$; Kayikci, M. ${ }^{1}$; Kousathanas, A. ${ }^{1}$; Lahnstein, L. ${ }^{1}$; Leigh, S. E. A. ${ }^{1}$; Leong, I. U. S. ${ }^{1}$; Lopez, F. J. ; Maleady-Crowe, F. ; Moutsianas, L. ${ }^{1,2}$; Mueller, M. ${ }^{1,2}$; Murugaesu, N. ${ }^{1}$; Need, A. C. ${ }^{1,2}$; O`Donovan P. ${ }^{1}$; Odhams, C. A. ${ }^{1}$; Patch, C. ${ }^{1,2}$; Perez-Gil, D. ${ }^{1}$; Pereira, M.B. ${ }^{1}$; Pullinger, J. ${ }^{1}$; Rahim, T. ${ }^{1}$; Rendon, A. ${ }^{1}$; Rogers, T. ${ }^{1}$; Savage, K. ${ }^{1}$; Sawant, K. ${ }^{1}$; Scott, R. H. ${ }^{1}$; Siddiq, A. ${ }^{1}$; Sieghart, A. ${ }^{1}$; Smith, S. C. ${ }^{1}$; Sosinsky, A. ${ }^{1,2}$; Stuckey, A. ${ }^{1}$; Tanguy, M. ${ }^{1}$; Thomas, E. R. A. ${ }^{1,2}$; Thompson, S. R. ${ }^{1}$; Tucci, A. ${ }^{1,2}$; Walsh, E. ${ }^{1}$; Welland, M. J. ${ }^{1}$; Williams, E. ; Witkowska, K. ${ }^{1,2}$; Wood, S. M. ${ }^{1,2}$.

1. Genomics England, London, UK

2. William Harvey Research Institute, Queen Mary University of London, London, EC1M 6BQ, UK. 
medRxiv preprint doi: https://doi.org/10.1101/2021.04.06.21255002; this version posted April 8, 2021. The copyright holder for this preprint (which was not certified by peer review) is the author/funder, who has granted medRxiv a license to display the preprint in perpetuity.

\section{References}

1. Van Tintelen JP, Pieper PG, Van Spaendonck-Zwarts KY, Van Den Berg MP.

Pregnancy, cardiomyopathies, and genetics. Cardiovascular research 2014;101(4):571-8.

2. Andrews RE, Fenton MJ, Ridout DA, Burch M, British Congenital Cardiac A. New-onset heart failure due to heart muscle disease in childhood: a prospective study in the United kingdom and Ireland. Circulation 2008;117(1):79-84.

3. Maron BJ, Towbin JA, Thiene G, Antzelevitch C, Corrado D, Arnett D, Moss AJ, Seidman CE, Young JB, American Heart A, Council on Clinical Cardiology HF, Transplantation C, Quality of C, Outcomes R, Functional G, Translational Biology Interdisciplinary Working G, Council on E, Prevention. Contemporary definitions and classification of the cardiomyopathies: an American Heart Association Scientific Statement from the Council on Clinical Cardiology, Heart Failure and Transplantation Committee; Quality of Care and Outcomes Research and Functional Genomics and Translational Biology Interdisciplinary Working Groups; and Council on Epidemiology and Prevention. Circulation 2006;113(14):1807-16.

4. Massin MM, Astadicko I, Dessy H. Epidemiology of heart failure in a tertiary pediatric center. Clinical cardiology 2008;31(8):388-91.

5. Webber SA. New-onset heart failure in children in the absence of structural congenital heart disease. Circulation 2008;117(1):11-2.

6. Lipshultz SE, Sleeper LA, Towbin JA, Lowe AM, Orav EJ, Cox GF, Lurie PR, McCoy KL, McDonald MA, Messere JE, Colan SD. The incidence of pediatric cardiomyopathy in two regions of the United States. The New England journal of medicine 2003;348(17):1647-55. 
medRxiv preprint doi: https://doi.org/10.1101/2021.04.06.21255002; this version posted April 8, 2021. The copyright holder for this preprint (which was not certified by peer review) is the author/funder, who has granted medRxiv a license to display the preprint in perpetuity. It is made available under a CC-BY-NC-ND 4.0 International license .

7. Jacoby D, McKenna WJ. Genetics of inherited cardiomyopathy. European heart journal 2012;33(3):296-304.

8. Towbin JA. Inherited cardiomyopathies. Circulation journal : official journal of the Japanese Circulation Society 2014;78(10):2347-56.

9. Watkins H, Ashrafian H, Redwood C. Inherited cardiomyopathies. The New England journal of medicine 2011;364(17):1643-56.

10. Marstrand P, Han L, Day SM, Olivotto I, Ashley EA, Michels M, Pereira AC, Wittekind SG, Helms A, Saberi S, Jacoby D, Ware JS, Colan SD, Semsarian C, Ingles J, Lakdawala NK, Ho CY, Investigators SH. Hypertrophic Cardiomyopathy With Left Ventricular Systolic Dysfunction: Insights From the SHaRe Registry. Circulation 2020;141(17):1371-1383.

11. Mathew J, Zahavich L, Lafreniere-Roula M, Wilson J, George K, Benson L, Bowdin S, Mital S. Utility of genetics for risk stratification in pediatric hypertrophic cardiomyopathy. Clin Genet 2018;93(2):310-319.

12. Wang L, Tan TC, Halpern EF, Neilan TG, Francis SA, Picard MH, Fei H, Hochberg EP, Abramson JS, Weyman AE, Kuter I, Scherrer-Crosbie M. Major Cardiac Events and the Value of Echocardiographic Evaluation in Patients Receiving Anthracycline-Based Chemotherapy. The American journal of cardiology 2015;116(3):442-6.

13. Rowin EJ, Maron MS, Wells S, Patel PP, Koethe BC, Maron BJ. Impact of Sex on Clinical Course and Survival in the Contemporary Treatment Era for Hypertrophic Cardiomyopathy. Journal of the American Heart Association 2019;8(21):e012041.

14. Jang JH, Shin SH, Beak YS, Ko KY, Kwon SW, Park SD, Woo SI, Kim DH, Kwan J. Impact of gender on heart failure presentation in non-obstructive hypertrophic cardiomyopathy. Heart and vessels 2020;35(2):214-222. 
medRxiv preprint doi: https://doi.org/10.1101/2021.04.06.21255002; this version posted April 8, 2021. The copyright holder for this preprint (which was not certified by peer review) is the author/funder, who has granted medRxiv a license to display the preprint in perpetuity. It is made available under a CC-BY-NC-ND 4.0 International license .

15. Ho CY, Day SM, Ashley EA, Michels M, Pereira AC, Jacoby D, Cirino AL, Fox JC, Lakdawala NK, Ware JS, Caleshu CA, Helms AS, Colan SD, Girolami F, Cecchi F, Seidman CE, Sajeev G, Signorovitch J, Green EM, Olivotto I. Genotype and Lifetime Burden of Disease in Hypertrophic Cardiomyopathy: Insights from the Sarcomeric Human Cardiomyopathy Registry (SHaRe). Circulation 2018;138(14):1387-1398.

16. Olivotto I, Maron MS, Adabag AS, Casey SA, Vargiu D, Link MS, Udelson JE, Cecchi F, Maron BJ. Gender-related differences in the clinical presentation and outcome of hypertrophic cardiomyopathy. Journal of the American College of Cardiology 2005;46(3):480-7.

17. Mohan SB, Parker M, Wehbi M, Douglass P. Idiopathic dilated cardiomyopathy: a common but mystifying cause of heart failure. Cleve Clin J Med 2002;69(6):481-7.

18. Genomes Project C, Abecasis GR, Altshuler D, Auton A, Brooks LD, Durbin RM, Gibbs RA, Hurles ME, McVean GA. A map of human genome variation from population-scale sequencing. Nature 2010;467(7319):1061-73.

19. Lek M, Karczewski KJ, Minikel EV, Samocha KE, Banks E, Fennell T, O'Donnell-Luria AH, Ware JS, Hill AJ, Cummings BB, Tukiainen T, Birnbaum DP, Kosmicki JA, Duncan LE, Estrada K, Zhao F, Zou J, Pierce-Hoffman E, Berghout J, Cooper DN, Deflaux N, DePristo M, Do R, Flannick J, Fromer M, Gauthier L, Goldstein J, Gupta N, Howrigan D, Kiezun A, Kurki MI, Moonshine AL, Natarajan P, Orozco L, Peloso GM, Poplin R, Rivas MA, Ruano-Rubio V, Rose SA, Ruderfer DM, Shakir K, Stenson PD, Stevens C, Thomas BP, Tiao G, Tusie-Luna MT, Weisburd B, Won HH, Yu D, Altshuler DM, Ardissino D, Boehnke M, Danesh J, Donnelly S, Elosua R, Florez JC, Gabriel SB, Getz G, Glatt SJ, Hultman CM, Kathiresan S, Laakso M, McCarroll S, McCarthy MI, McGovern D, McPherson R, Neale BM, Palotie A, Purcell SM, Saleheen D, Scharf JM, Sklar P, Sullivan PF, Tuomilehto J, Tsuang MT, Watkins HC, Wilson 
medRxiv preprint doi: https://doi.org/10.1101/2021.04.06.21255002; this version posted April 8, 2021. The copyright holder for this preprint (which was not certified by peer review) is the author/funder, who has granted medRxiv a license to display the preprint in perpetuity. It is made available under a CC-BY-NC-ND 4.0 International license.

JG, Daly MJ, MacArthur DG, Exome Aggregation C. Analysis of protein-coding genetic variation in 60,706 humans. Nature 2016;536(7616):285-91.

20. Petrovski S, Wang Q, Heinzen EL, Allen AS, Goldstein DB. Genic intolerance to functional variation and the interpretation of personal genomes. PLoS genetics 2013;9(8):e1003709.

21. Havrilla JM, Pedersen BS, Layer RM, Quinlan AR. A map of constrained coding regions in the human genome. Nature genetics 2019;51(1):88-95.

22. Papaz T, Safi M, Manickaraj AK, Ogaki C, Breaton Kyryliuk J, Burrill L, Dodge C, Chant-Gambacort C, Walter LL, Rosenberg H, Mondal T, Smythe J, Lougheed J, Bergin L, Gordon E, Chitayat D, Oechslin E, Mital S. Factors influencing participation in a populationbased biorepository for childhood heart disease. Pediatrics 2012;130(5):e1198-205.

23. Caulfield M, Davies J, Dennys M, Elbahy L, Fowler T, Hill S, Hubbard T, Jostins L, Maltby N, Mahon-Pearson J, McVean G, Nevin-Ridley K, Parker M, Parry V, Rendon A, Riley

L, Turnbull C, Woods K. The National Genomics Research and Healthcare Knowledgebase. 2019.

24. Elliott P, Andersson B, Arbustini E, Bilinska Z, Cecchi F, Charron P, Dubourg O, Kuhl U, Maisch B, McKenna WJ, Monserrat L, Pankuweit S, Rapezzi C, Seferovic P, Tavazzi L, Keren A. Classification of the cardiomyopathies: a position statement from the European Society Of Cardiology Working Group on Myocardial and Pericardial Diseases. European heart journal 2008;29(2):270-6.

25. Yao RA, Akinrinade O, Chaix M, Mital S. Quality of whole genome sequencing from blood versus saliva derived DNA in cardiac patients. BMC medical genomics 2020;13(1):11. 
medRxiv preprint doi: https://doi.org/10.1101/2021.04.06.21255002; this version posted April 8, 2021. The copyright holder for this preprint (which was not certified by peer review) is the author/funder, who has granted medRxiv a license to display the preprint in perpetuity. It is made available under a CC-BY-NC-ND 4.0 International license .

26. McLaren W, Gil L, Hunt SE, Riat HS, Ritchie GR, Thormann A, Flicek P, Cunningham F. The Ensembl Variant Effect Predictor. Genome biology 2016;17(1):122.

27. Ng PC, Henikoff S. SIFT: Predicting amino acid changes that affect protein function. Nucleic acids research 2003;31(13):3812-4.

28. Adzhubei I, Jordan DM, Sunyaev SR. Predicting functional effect of human missense mutations using PolyPhen-2. Current protocols in human genetics / editorial board, Jonathan L Haines [et al] 2013;Chapter 7:Unit7 20.

29. Kircher M, Witten DM, Jain P, O'Roak BJ, Cooper GM, Shendure J. A general framework for estimating the relative pathogenicity of human genetic variants. Nature genetics 2014;46(3):310-5.

30. Karczewski KJ, Francioli LC, Tiao G, Cummings BB, Alfoldi J, Wang Q, Collins RL, Laricchia KM, Ganna A, Birnbaum DP, Gauthier LD, Brand H, Solomonson M, Watts NA, Rhodes D, Singer-Berk M, England EM, Seaby EG, Kosmicki JA, Walters RK, Tashman K, Farjoun Y, Banks E, Poterba T, Wang A, Seed C, Whiffin N, Chong JX, Samocha KE, PierceHoffman E, Zappala Z, O'Donnell-Luria AH, Minikel EV, Weisburd B, Lek M, Ware JS, Vittal C, Armean IM, Bergelson L, Cibulskis K, Connolly KM, Covarrubias M, Donnelly S, Ferriera S, Gabriel S, Gentry J, Gupta N, Jeandet T, Kaplan D, Llanwarne C, Munshi R, Novod S, Petrillo N, Roazen D, Ruano-Rubio V, Saltzman A, Schleicher M, Soto J, Tibbetts K, Tolonen C, Wade G, Talkowski ME, Genome Aggregation Database C, Neale BM, Daly MJ, MacArthur DG. The mutational constraint spectrum quantified from variation in 141,456 humans. Nature 2020;581(7809):434-443.

31. UniProt C. UniProt: a worldwide hub of protein knowledge. Nucleic acids research 2019;47(D1):D506-D515. 
medRxiv preprint doi: https://doi.org/10.1101/2021.04.06.21255002; this version posted April 8, 2021. The copyright holder for this preprint (which was not certified by peer review) is the author/funder, who has granted medRxiv a license to display the preprint in perpetuity. It is made available under a CC-BY-NC-ND 4.0 International license .

32. Meyer D, Zeileis A, Hornik K. vcd: Visualizing Categorical Data. R package version 1.48. 2020.

33. Akinrinade O, Alastalo TP, Koskenvuo JW. Relevance of truncating titin mutations in dilated cardiomyopathy. Clin Genet 2016;90(1):49-54.

34. Akinrinade O, Ollila L, Vattulainen S, Tallila J, Gentile M, Salmenpera P, Koillinen H, Kaartinen M, Nieminen MS, Myllykangas S, Alastalo TP, Koskenvuo JW, Helio T. Genetics and genotype-phenotype correlations in Finnish patients with dilated cardiomyopathy. European heart journal 2015;36(34):2327-37.

35. Herman DS, Lam L, Taylor MR, Wang L, Teekakirikul P, Christodoulou D, Conner L, DePalma SR, McDonough B, Sparks E, Teodorescu DL, Cirino AL, Banner NR, Pennell DJ, Graw S, Merlo M, Di Lenarda A, Sinagra G, Bos JM, Ackerman MJ, Mitchell RN, Murry CE, Lakdawala NK, Ho CY, Barton PJ, Cook SA, Mestroni L, Seidman JG, Seidman CE. Truncations of titin causing dilated cardiomyopathy. The New England journal of medicine 2012;366(7):619-28.

36. Spudich JA, Aksel T, Bartholomew SR, Nag S, Kawana M, Yu EC, Sarkar SS, Sung J, Sommese RF, Sutton S, Cho C, Adhikari AS, Taylor R, Liu C, Trivedi D, Ruppel KM. Effects of hypertrophic and dilated cardiomyopathy mutations on power output by human beta-cardiac myosin. The Journal of experimental biology 2016;219(Pt 2):161-7.

37. Debold EP, Schmitt JP, Patlak JB, Beck SE, Moore JR, Seidman JG, Seidman C, Warshaw DM. Hypertrophic and dilated cardiomyopathy mutations differentially affect the molecular force generation of mouse alpha-cardiac myosin in the laser trap assay. American journal of physiology Heart and circulatory physiology 2007;293(1):H284-91. 
medRxiv preprint doi: https://doi.org/10.1101/2021.04.06.21255002; this version posted April 8, 2021. The copyright holder for this preprint (which was not certified by peer review) is the author/funder, who has granted medRxiv a license to display the preprint in perpetuity. It is made available under a CC-BY-NC-ND 4.0 International license .

38. Pugh TJ, Kelly MA, Gowrisankar S, Hynes E, Seidman MA, Baxter SM, Bowser M, Harrison B, Aaron D, Mahanta LM, Lakdawala NK, McDermott G, White ET, Rehm HL, Lebo M, Funke BH. The landscape of genetic variation in dilated cardiomyopathy as surveyed by clinical DNA sequencing. Genetics in medicine : official journal of the American College of Medical Genetics 2014;16(8):601-8.

39. Roberts AM, Ware JS, Herman DS, Schafer S, Baksi J, Bick AG, Buchan RJ, Walsh R, John S, Wilkinson S, Mazzarotto F, Felkin LE, Gong S, JA LM, Cunningham F, Flannick J, Gabriel SB, Altshuler DM, Macdonald PS, Heinig M, Keogh AM, Hayward CS, Banner NR, Pennell DJ, O'Regan DP, San TR, de Marvao A, TJ WD, Gulati A, Birks EJ, Yacoub MH, Radke M, Gotthardt M, Wilson JG, O'Donnell CJ, Prasad SK, PJ RB, Fatkin D, Hubner N, Seidman JG, Seidman CE, Cook SA. Integrated allelic, transcriptional, and phenomic dissection of the cardiac effects of titin truncations in health and disease. Science translational medicine 2015;7(270):270ra6.

40. Hu LR, Kontrogianni-Konstantopoulos A. Proteomic Analysis of Myocardia Containing the Obscurin R4344Q Mutation Linked to Hypertrophic Cardiomyopathy. Frontiers in physiology 2020;11:478.

41. Grogan A, Kontrogianni-Konstantopoulos A. Unraveling obscurins in heart disease. Pflugers Archiv : European journal of physiology 2019;471(5):735-743.

42. Mayosi BM, Fish M, Shaboodien G, Mastantuono E, Kraus S, Wieland T, Kotta MC, Chin A, Laing N, Ntusi NB, Chong M, Horsfall C, Pimstone SN, Gentilini D, Parati G, Strom TM, Meitinger T, Pare G, Schwartz PJ, Crotti L. Identification of Cadherin 2 (CDH2) Mutations in Arrhythmogenic Right Ventricular Cardiomyopathy. Circulation Cardiovascular genetics $2017 ; \mathbf{1 0}(2)$. 
medRxiv preprint doi: https://doi.org/10.1101/2021.04.06.21255002; this version posted April 8, 2021. The copyright holder for this preprint (which was not certified by peer review) is the author/funder, who has granted medRxiv a license to display the preprint in perpetuity. It is made available under a CC-BY-NC-ND 4.0 International license.

43. Roger VL, Go AS, Lloyd-Jones DM, Benjamin EJ, Berry JD, Borden WB, Bravata DM, Dai S, Ford ES, Fox CS, Fullerton HJ, Gillespie C, Hailpern SM, Heit JA, Howard VJ, Kissela BM, Kittner SJ, Lackland DT, Lichtman JH, Lisabeth LD, Makuc DM, Marcus GM, Marelli A, Matchar DB, Moy CS, Mozaffarian D, Mussolino ME, Nichol G, Paynter NP, Soliman EZ, Sorlie PD, Sotoodehnia N, Turan TN, Virani SS, Wong ND, Woo D, Turner MB, American Heart Association Statistics C, Stroke Statistics S. Executive summary: heart disease and stroke statistics--2012 update: a report from the American Heart Association. Circulation 2012;125(1):188-97.

44. McNamara DM, Starling RC, Cooper LT, Boehmer JP, Mather PJ, Janosko KM, Gorcsan J, 3rd, Kip KE, Dec GW, Investigators I. Clinical and demographic predictors of outcomes in recent onset dilated cardiomyopathy: results of the IMAC (Intervention in Myocarditis and Acute Cardiomyopathy)-2 study. Journal of the American College of Cardiology 2011;58(11):1112-8. 45. Regitz-Zagrosek V, Seeland U. Sex and gender differences in myocardial hypertrophy and heart failure. Wien Med Wochenschr 2011;161(5-6):109-16.

46. Lee LV, Foody JM. Women and heart disease. Cardiol Clin 2011;29(1):35-45. 


\section{Figure Legends}

Figure 1. Variant yield by cardiomyopathy phenotypes. (a) Patients with variants in Tier 1 genes (471 pediatric, 921 adult cases). A higher proportion of pediatric patients (brown) harbored rare deleterious variants in Tier 1 cardiomyopathy genes compared to adult patients (green) ( $\mathrm{p}=0.04)$. (b) There was no difference in frequency of multiple deleterious variants in cardiomyopathy genes between pediatric and adult cases. *p $<0.05 ; * \mathrm{*}<0.001$ CMP, cardiomyopathy; HCM, hypertrophic cardiomyopathy; DCM, dilated cardiomyopathy

Figure 2. Constrained coding region (CCR) score of deleterious variants in all cases and controls. (a, b) Density plots of CCR scores, and (c, d) Empirical cumulative probability distribution of CCR scores of deleterious variants identified in cardiomyopathy cases $(n=1397)$ and in gnomAD reference controls $(\mathrm{n}=125,748)$. Variant $\mathrm{CCR}$ scores were higher in cardiomyopathy cases compared to gnomAD reference controls across all cardiomyopathy genes (KS test $\left.\mathrm{p}=2.19 \times 10^{-14}\right)$ and in the subset of Tier 1 genes $\left(\mathrm{KS}\right.$ test $\left.\mathrm{p}=1.11 \times 10^{-15}\right)$. CCR, constrained coding regions; CMP, cardiomyopathy; gnomAD, Genome Aggregation Database; KS, Kolmogorov-Smirnov test

Figure 3. CCR score of deleterious variants stratified by age. (a-d) Density plots of CCR scores, and (e-h) Empirical cumulative probability distribution of CCR scores of deleterious variants identified in pediatric $(\mathrm{n}=471)$ and adult cardiomyopathy cases $(\mathrm{n}=921)$. Variant $\mathrm{CCR}$ scores were higher in pediatric versus adult cardiomyopathy cases across all cardiomyopathy 
medRxiv preprint doi: https://doi.org/10.1101/2021.04.06.21255002; this version posted April 8, 2021. The copyright holder for this preprint (which was not certified by peer review) is the author/funder, who has granted medRxiv a license to display the preprint in perpetuity.

It is made available under a CC-BY-NC-ND 4.0 International license .

genes $(\mathrm{KS}$ test $\mathrm{p}=0.0039)$, in the subset of Tier 1 genes $(\mathrm{p}=0.0005)$ and in sarcomeric genes $(\mathrm{p}=0.0031)$, but not different in non-sarcomeric genes $(\mathrm{p}=0.271)$.

CCR, constrained coding regions; CMP, cardiomyopathy; KS, Kolmogorov-Smirnov test

Figure 4. Genes harboring deleterious variants stratified by age. Bar plots showing genes harboring deleterious variants in patients with (a) any cardiomyopathy ( $\mathrm{n}=1397)$, (b) only hypertrophic cardiomyopathy $(n=768)$, and (c) only dilated cardiomyopathy $(n=435) . * p<0.05$ between pediatric and adult patients. (d-f) Volcano plots showing log odds ratio of the frequency of variants between pediatric and adult patients with (d) any cardiomyopathy, (e) hypertrophic cardiomyopathy only, and (f) dilated cardiomyopathy only. MYH7, TNNT2 and VCL were more frequently mutated in pediatric patients, and $T T N$ and $O B S C N$ were more frequently mutated in adult patients.

NS, no significant difference (grey); $\log 2 \mathrm{OR}$, genes meeting $\log 2(\mathrm{OR}) \geq 1.5$ between pediatric and adult (green); $\mathrm{P}$, genes with $\mathrm{p}<0.05$ for variant burden between pediatric and adult (blue); $\mathrm{p}$ $\& \log 2$ OR - genes with $\mathrm{p}<0.05$ for variant burden and with at least 1.5 odds ratio between pediatric and adult cases (red).

HCM, hypertrophic cardiomyopathy; DCM, dilated cardiomyopathy; OR, odds ratio

Figure 5. Gene categories harboring rare deleterious variants stratified by age. The forest plot shows the log odds ratio comparing proportion of variant carriers between 471 pediatric and 926 adult patients for different gene categories across different cardiomyopathy subtypes.

Sarcomeric genes were more frequently mutated in pediatric cases; desmosomal genes were 
medRxiv preprint doi: https://doi.org/10.1101/2021.04.06.21255002; this version posted April 8, 2021. The copyright holder for this preprint (which was not certified by peer review) is the author/funder, who has granted medRxiv a license to display the preprint in perpetuity.

It is made available under a CC-BY-NC-ND 4.0 International license .

more frequently mutated in adult patients. Filled circles indicate significant differences between pediatric and adult patients.

CMP, cardiomyopathy (black); DCM, dilated cardiomyopathy (blue), HCM, hypertrophic cardiomyopathy (red)

Figure 6. Spatial distribution of deleterious variants within protein domains. Each protein is linearly depicted with uniprot domain information. Light salmon bars show the constrained coding region scores across the entire protein. (a) MYH7 showing head, neck and rod/tail regions. Unlike variants in adult patients, deleterious variants in pediatric patients were nonuniformly distributed with clustering within head and neck domains and fewer variants in the tail domain ( $\mathrm{p}=0.00084)$. (b) MYBPC3 showing the immunoglobulin and fibronectin type 3 domains. Deleterious variants clustered in $\mathrm{C} 5, \mathrm{C} 7$, and $\mathrm{C} 10$ domains ( $\mathrm{p}=0.023)$, but this distribution did not differ between pediatric $(n=471)$ and adult $(n=926)$ patients. $(\mathbf{c})$ TTN showing the four regions and all domains. The light blue bars under titin show the transcript count index. TTN truncating variants clustered in the A-band domain in adult patients $(\mathrm{p}=0.0035)$ but were uniformly distributed in pediatric patients. (d) OBSCN domains. Deleterious variants clustered within the protein kinase domains of the genes in adult patients $(\mathrm{p}=0.033)$ but not in pediatric patients. Non-random distribution of variants with each protein was assessed using Kolmogorov-Smirnov goodness-of-fit test.

CCR, Constrained coding region; TCI, transcript count index

Figure 7. CCR score and affected genes harboring deleterious variants in males and

females. (a-c) Density plots of CCR scores, and (d-f) Empirical cumulative probability 
medRxiv preprint doi: https://doi.org/10.1101/2021.04.06.21255002; this version posted April 8, 2021. The copyright holder for this preprint (which was not certified by peer review) is the author/funder, who has granted medRxiv a license to display the preprint in perpetuity. It is made available under a CC-BY-NC-ND 4.0 International license.

distribution of CCR scores of deleterious variants identified in 1397 cardiomyopathy cases and in gnomAD reference controls $(n=125,748)$ stratified by sex. (d) There was no difference in variant CCR scores between male and female reference controls in gnomAD. In cardiomyopathy cases, variant CCR scores were higher in female $(n=526)$ compared to male patients $(n=871)(\mathbf{e})$ across all cardiomyopathy genes (KS test $\mathrm{p}=0.002)$ and $(\mathbf{f})$ in the subset of Tier 1 genes $(\mathrm{p}=0.019)$. (g) Bar plots showing genes harboring rare deleterious variants across all cardiomyopathy patients ( 871 males, 526 females). ${ }^{*} \mathrm{p}<0.05$ between male and female patients. (h) The forest plot shows the log odds ratio comparing proportion of variant carriers between male and female patients for different gene categories across cardiomyopathy subtypes. Except for more male patients harboring more $C P T 2$ variants $(\mathrm{p}=0.028)$, there was no difference in affected genes or gene categories between male and female patients.

$\mathrm{CCR}$, constrained coding regions; CMP, cardiomyopathy; gnomAD, Genome Aggregation Database; CMP, cardiomyopathy (black); DCM, dilated cardiomyopathy (blue), HCM, hypertrophic cardiomyopathy (red) 
Table 1. Characteristics of study cohort

\begin{tabular}{|c|c|c|c|c|}
\hline & All $(n=1397)$ & $\begin{array}{l}\text { Pediatric } \\
(n=471)\end{array}$ & $\begin{array}{c}\text { Adult } \\
(n=926)\end{array}$ & p-value \\
\hline Mean age at diagnosis (years) & $31.4 \pm 21.8$ & $4.8 \pm 5.9$ & $44.0 \pm 13.7$ & $2.2 \times 10^{-16}$ \\
\hline Male, n (\%) & $871(62.3)$ & $284(60.3)$ & $587(63.4)$ & 0.28 \\
\hline \multicolumn{5}{|l|}{ Cardiomyopathy subtypes, n (\%) } \\
\hline $\mathrm{HCM}$ & $768(55.0)$ & $223(47.3)$ & $545(58.9)$ & $5.6 \times 10^{-5}$ \\
\hline $\mathrm{DCM}$ & $435(31.1)$ & $175(37.2)$ & $260(28.1)$ & $6.7 \times 10^{-4}$ \\
\hline $\mathrm{ACM}$ & $116(8.3)$ & $20(4.2)$ & $96(10.4)$ & $1.4 \times 10^{-4}$ \\
\hline LVNC & $58(4.2)$ & $33(7.0)$ & $25(2.7)$ & $2.4 \times 10^{-4}$ \\
\hline $\mathrm{RCM}$ & $20(1.4)$ & $20(4.2)$ & - & \\
\hline \multicolumn{5}{|c|}{ n (\%) of variant-positive* patients in all genes } \\
\hline All cardiomyopathy $(\mathrm{n}=1397)$ & $635(45.5)$ & $218(46.3)$ & $417(45.0)$ & 0.70 \\
\hline $\mathrm{HCM}(\mathrm{n}=768)$ & $330(43.0)$ & $105(47.1)$ & $225(41.3)$ & 0.16 \\
\hline $\operatorname{DCM}(n=435)$ & $215(49.4)$ & $79(45.1)$ & $136(52.3)$ & 0.17 \\
\hline \multicolumn{5}{|c|}{ n (\%) of variant-positive* patients in Tier 1 genes } \\
\hline All cardiomyopathy $(\mathrm{n}=1397)$ & $395(28.3)$ & $150(31.8)$ & $245(26.5)$ & 0.04 \\
\hline $\mathrm{HCM}(\mathrm{n}=768)$ & $201(26.2)$ & $75(33.6)$ & $126(23.1)$ & 0.004 \\
\hline $\operatorname{DCM}(n=435)$ & $144(33.1)$ & $56(32 \%)$ & $88(34 \%)$ & 0.77 \\
\hline
\end{tabular}

*Variant positive $=$ presence of a rare, deleterious variant in a cardiomyopathy gene p value for pediatric versus adult cases 
medRxiv preprint doi: https://doi.org/10.1101/2021.04.06.21255002; this version posted April 8, 2021. The copyright holder for this preprint (which was not certified by peer review) is the author/funder, who has granted medRxiv a license to display the preprint in perpetuity. It is made available under a CC-BY-NC-ND 4.0 International license.

HCM, hypertrophic cardiomyopathy; DCM, dilated cardiomyopathy; ACM, arrhythmogenic cardiomyopathy; LVNC, left ventricular non-compaction cardiomyopathy; RCM, restrictive cardiomyopathy 

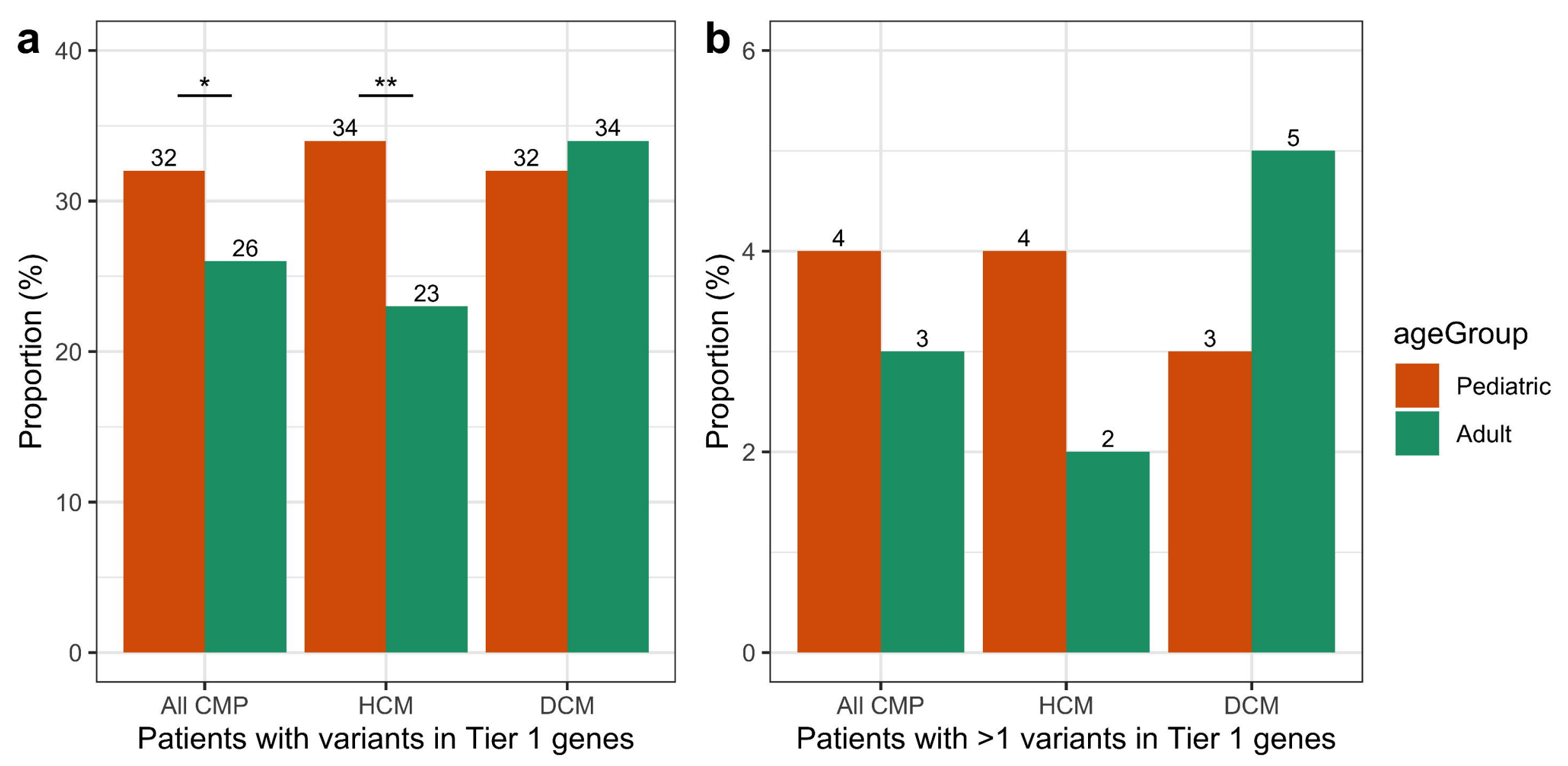


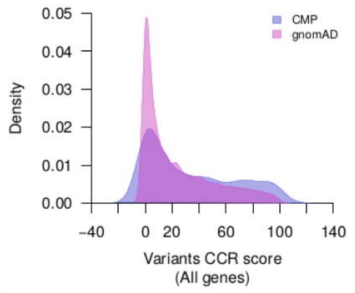

C
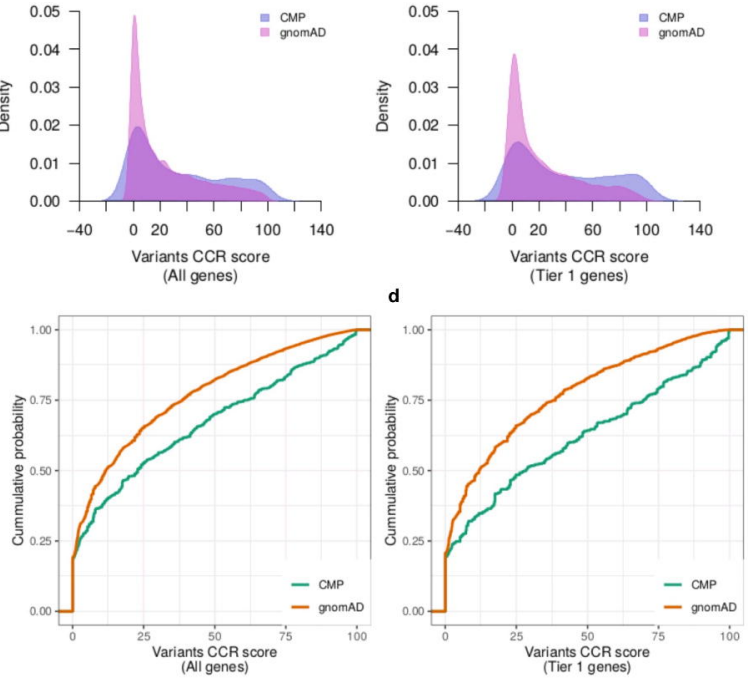


\section{a}

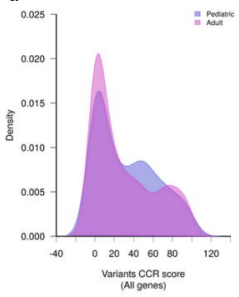

e

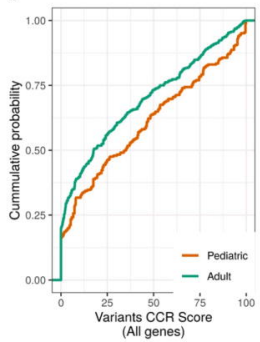

b

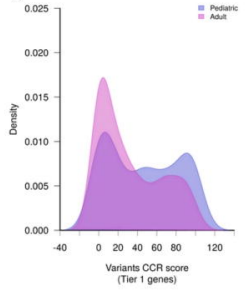

f

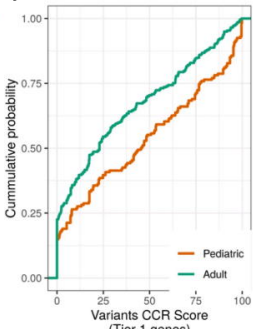

(Tier 1 genes)

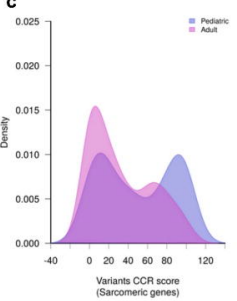

d

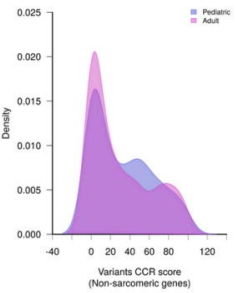

h
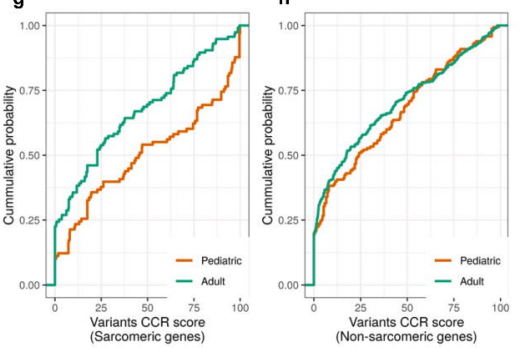


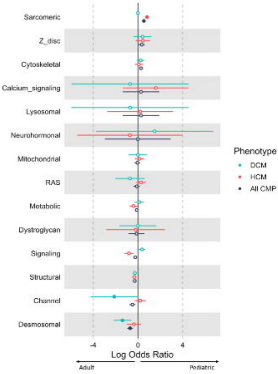


a

Ped

$|\quad|||||||||||||||$

Adult

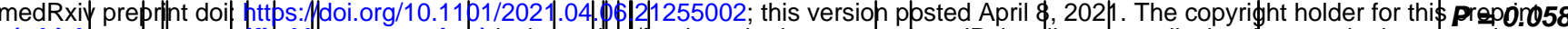
(which was not cettified by peer review) is the authol/funder, who has granted medRxiv a license to display the preprint in pe petuity.

All

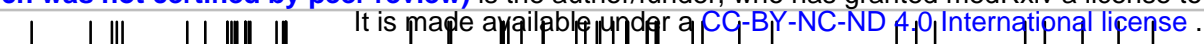

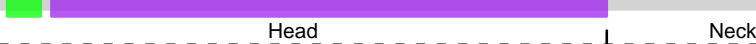

CCRs

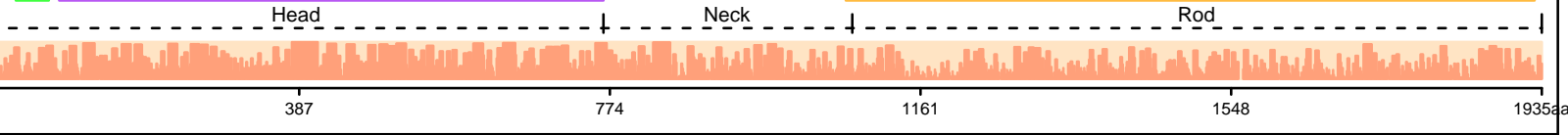

$\square$ Myosin N-terminal SH3-like domain $\square$ Myosin head (motor domain)

Myosin tail

-Missense - LoF

b

MYBPC3

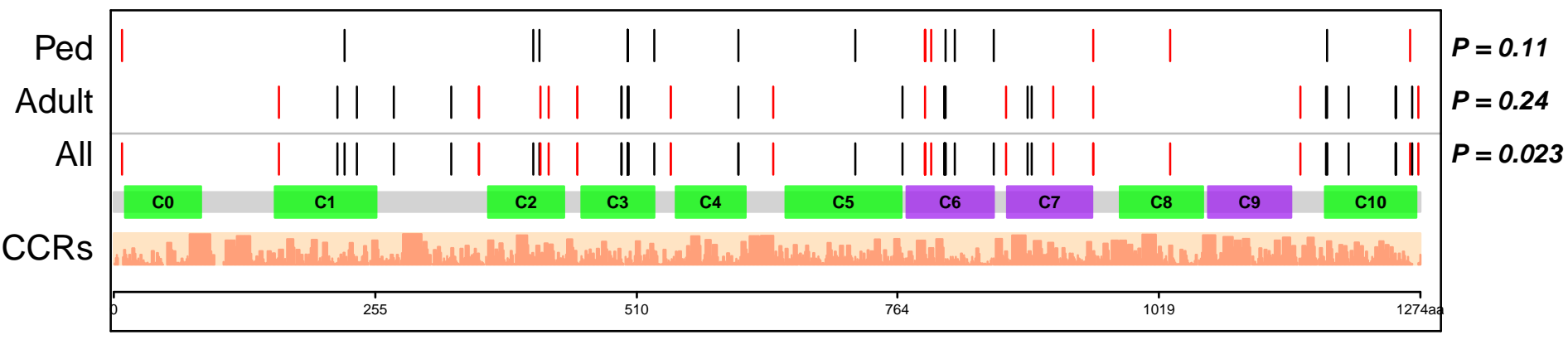

$\square$ Ig-like domain $\quad \square F N$ type-III domain

-Missense - LoF

C

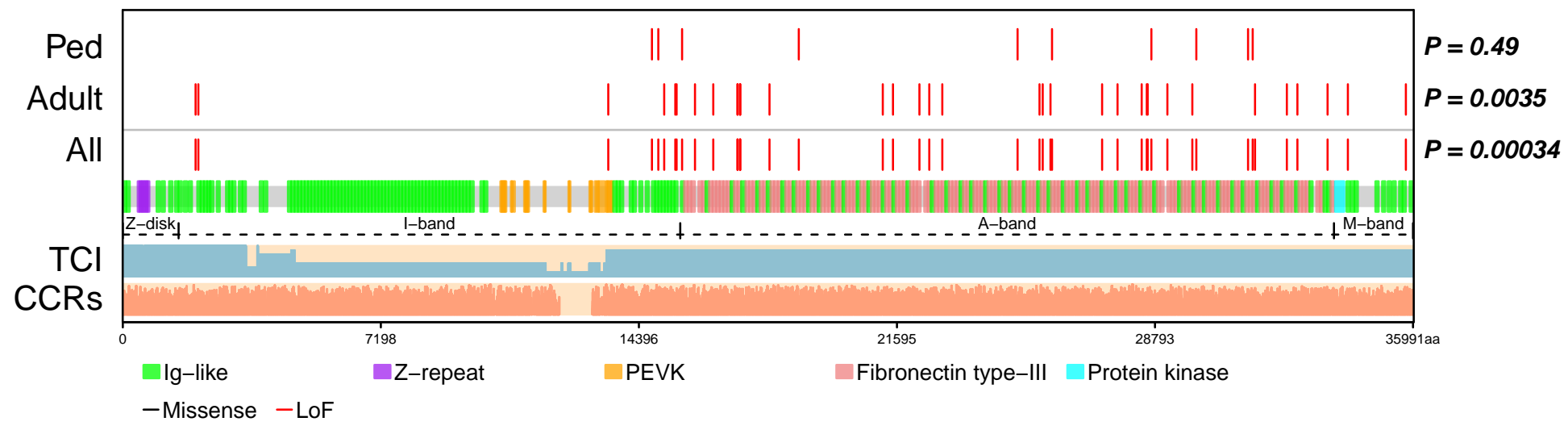

d

OBSCN

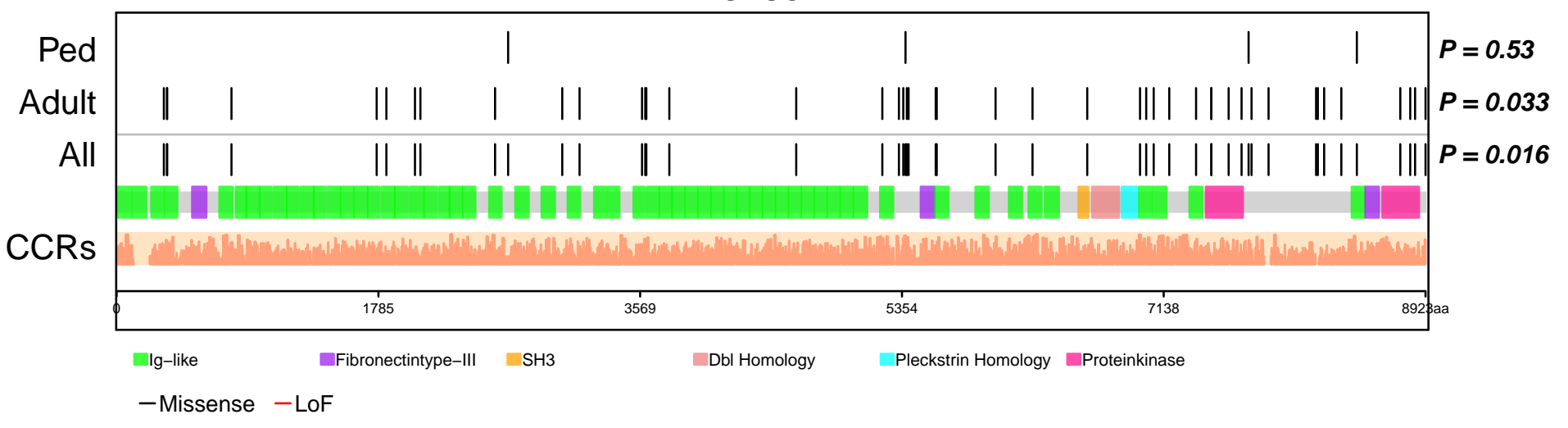


a

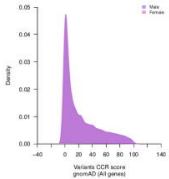

d

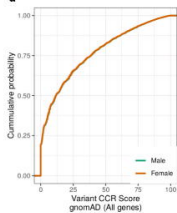

IT

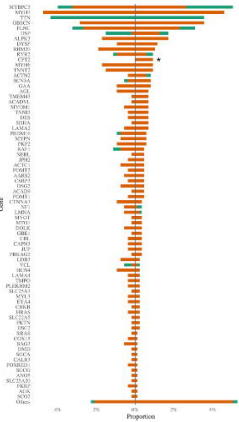

b

0
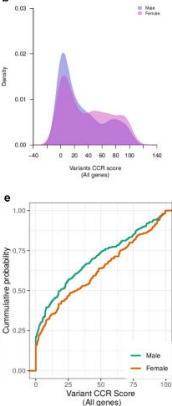

(Al genes)

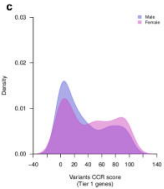

$f$

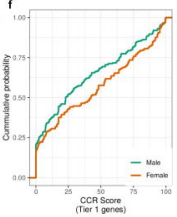

h

Cacum_signaing

Mitochondrial

Metabolic

Neurotominonal

Structura

Sarcomeric

seTse

Lat 